\title{
SALEZJANIE A MEDIA
}

\begin{abstract}
Streszczenie: Salezjanie traktują środki komunikacji społecznej jako narzędzia służące pomocą w szeroko rozumianym wychowaniu i duszpasterstwie. Dlatego też umieszczają je w kontekście wypracowanego przez siebie i jasno sformułowanego systemu komunikacji społecznej, który nawiązuje w sposób bezpośredni do stylu komunikacji wprowadzonego przez księdza Bosko na Valdocco. A postoł młodzieży, który był także pisarzem, publicystą, wydawcą oraz dystrybutorem, bardzo cenił tradycyjne i dostępne mu środki społecznej komunikacji - teatr, akademie, muzykę. Nie wyobrażał sobie wychowania bez wprowadzania młodych w kulturę, którą współtworzyli wychowankowie. Szeroko rozumianą komunikację społeczną wykorzystywał również w zabawach i rywalizacji sportowej. To wszystko tworzyło echosystem, czyli taki sposób komunikacji, w której nadawca jest jednocześnie odbiorcą, odbiorca - nadawcą, a dialog i wzajemne słuchanie jest podstawową formą nawiązywania kontaktu i wymiany idei.
\end{abstract}

Słowa kluczowe: nowe media, komunikacja, salezjanie, Jan Bosko

\section{Media i komunikacja - kontekst Valdocco}

Salezjanie traktują środki komunikacji społecznej jako narzędzia służące pomocą w szeroko rozumianym wychowaniu i duszpasterstwie. Dlatego też umieszczają je w kontekście wypracowanego przez siebie i jasno sformułowanego systemu komunikacji społecznej, którego pierwsza wersja ukazała się w roku 2005, a druga poprawiona - w roku 2011 (Sistema Salesiano di Comunicazione Sociale. Linee Orientative per la Congregazione Salesiana. Roma 2005 i 2011). Dlaczego raczej komunikacja, a nie media? Aby to ujęcie lepiej zrozumieć, należy udać się na Valdocco i przyjrzeć koncepcji duszpasterstwa i wychowania wprowadzonej w życie przez Jana Bosko. Ten piemoncki ksiądz bardzo dobrze rozumiał, że swojego duchowego oddziaływania nie może ograniczyć wyłącznie do ambony i kościoła. W związku z tym przyjął, że każda forma dotarcia do odbiorcy - tak dziecka, nastolatka, jak i dorosłego - jest dobra, jeśli jej celem jest troska o zbawienie dusz. Ksiądz Bosko wykorzystywał więc swoje zdolności pisarskie, publicystyczne, artystyczne, ale także organizacyjne. 
Jak zatem wyglądał system komunikacji społecznej ks. Jana Bosko? Idee wychowawcze i religijne apostoł młodych przekazywał - jak już wspomniałem - nie tylko w formie bezpośredniej (mówiący - słuchacz), ale także - na przykład - za pośrednictwem napisanych przez siebie biografii młodych ludzi. Pierwsza biografia, jaka wyszła spod jego pióra, była poświęcona koledze z lat szkolnych i seminaryjnych z Chieri, Alojzemu Comollowi. Kolejnymi były szkice o św. Dominiku Savio, Michale Magone i Franciszku Besucco. Tych zmarłych w młodym wieku ludzi Jan Bosko stawiał za przykłady życia. Książki o nich, czytane przez kolejne pokolenia wychowanków, pełniły więc niejako rolę cichego wychowawcy, inspirowały do lepszego życia i zachęcały do pójścia tą samą drogą.

Ks. Bosko nie tylko nadaje pewien bardzo ważny dla siebie komunikat, ale także czeka na informację zwrotną. Wierzy, że jeśli czytelnika zachwyci biografia jego rówieśnika, to podejmie on trud pójścia tą samą drogą duchowego i ludzkiego wzrostu. I tak rzeczywiście było. Na przykład Dominik Savio czytał biografię Alojzego Comolla i inspirował się jego postawą.

Ks. Bosko pisarz to również autor i wydawca książek przeznaczonych dla dorosłego czytelnika. W jednym z listów okólnych szeroko nakreślił swoje zdanie na temat roli, jaką przypisywał książce (List okólny o rozpowszechnianiu dobrych książek $z 19$ marca 1885 r.). Dla niego książka pełniła rolę katechety, kaznodziei, przewodnika duchowego. (Przykład z listu okólnego na temat rozpowszechniania dobrych książek). Sam doświadczył takiego jej oddziaływania w dzieciństwie. Wówczas jego przewodnikiem duchowym oraz nauczycielem był ks. Jan Melchior Calosso. Z książkami od tamtego czasu nigdy się nie rozstawał. Co więcej, kiedy uczęszczał do szkoły średniej i dysponował bardzo skromną sumą pieniędzy, zawsze przewidywał ich zakup albo wypożyczenie w swoich wydatkach.

Ks. Bosko to także menedżer wydawniczy. Zaczął jako pisarz, następnie stał się wydawcą, a w końcu także właścicielem drukarni. Stworzył ponadto system dystrybucji, dając specjalne zniżki tym, którzy włączali się w rozpowszechnianie dobrych książek. Mamy więc przed sobą nowoczesnego duszpasterza, który nie tylko czeka na wiernych w kościele, ale towarzyszy im także poza nim za pomocą dobrego tekstu, dzięki któremu w samotności i intymności mogą formować siebie duchowo.

Ks. Bosko kochał tradycyjne środki społecznej komunikacji - teatr, akademie, muzykę. Nie wyobrażał sobie wychowania bez wprowadzania młodych w kulturę, której twórcami byli wychowankowie. Tworzyli oni grupy teatralne, orkiestry dęte i symfoniczne, wielogłosowe chóry. Ks. Bosko bardzo umiejętnie uczył wychowanków smakowania kultury, wrażliwości na estetykę i przede wszystkim radości z tworzenia kultury i uczestniczenia w niej. Wielka rodzina wychowawcza rozwijała ich, byli dla siebie nawzajem i aktorami, i widownią, i chórzystami, i słuchaczami.

System komunikacji międzyludzkiej na Valdocco wpisany był także w zabawy i gry sportowe. Inną z form oddziaływania były jednozdaniowe sentencje 
rozwieszone w różnych miejscach. Wymienione elementy tworzyły dobrze przemyślany system komunikacji społecznej, nawet jeśli nie był on teoretycznie opisany.

\section{System komunikacji w ujęciu salezjańskim}

W opozycji do używania środków społecznego przekazu, które sugerują w praktyce jeden kierunek transmisji: od nadawcy do odbiorcy, salezjanie wolą mówić o komunikacji społecznej, a jej założenia są następujące:

Wzorem sposobu komunikowania tego, co chcemy przekazać, jest Jezus Chrystus, jego sposób rozmawiania z ludźmi różnych warstw społecznych, doświadczających różnych przeżyć duchowych czy różnorako doświadczonych życiowo.

Każdy z nas jest komunikatorem. My słowa „komunikator” używamy do określenia narzędzia służącego do komunikacji. W niektórych językach nazywa się tak również człowieka, który ma coś do przekazania, ogłoszenia. Mam świadomość ułomności i niepoprawności użycia tego słowa w języku polskim, ale do oddania istoty komunikowania się w stylu salezjańskim pozwolę sobie go użyć.

Każdy jest komunikatorem i wszystko jest komunikacją, tylko wyrażoną w różny sposób, między innymi za pomocą: słów, gestów, mimiki, sposobu ubierania się itp.

Komunikacja opiera się na echosystemie - to określenie obrazuje, w jaki sposób przebiega, że jest niczym echo. W takim systemie nadawca jest jednocześnie odbiorcą, a odbiorca nadawcą, mówiący jest jednocześnie słuchaczem itd. Ważną rolę odgrywa więc dialog, współpraca, wzajemne oddziaływanie.

Dobieramy takie formy komunikacji, które w sposób wiarygodny i skuteczny przekażą proponowane przez nas treści.

System komunikacji wewnątrz Zgromadzenia Salezjańskiego dotyczy czterech wymiarów: animacji, formacji, informacji i produkcji. Dopiero w tym punkcie dochodzimy do narzędzi, czyli: telewizji, radia, internetu, książek, telefonów itp.

Szczególny nacisk jest położony na animację i formację. Podkreśla się, że dzisiaj wszyscy potrzebujemy formacji pod kątem właściwego korzystania ze współczesnych mediów oraz rozumienia ich mechanizmów. Niektórzy salezjanie wprost zwracają uwagę na związek komunikacji społecznej, środków społecznego przekazu i współczesnej duchowości. Jasno wypracowany system pomaga w tym, aby narzędzia nie wyszły przed treść przekazu.

\section{Dzisiejsze oratorium}

Umberto Eco w szkicu poświęconym św. Janowi Bosko i jego oratorium wychwala wychowawcę z Turynu za niezwykłe wyczucie środków komunikacji społecznej, które miał do dyspozycji. Ksiądz Bosko, zdaniem Eco, już wtedy korzystał z wielu rozproszonych kanałów komunikacji, które były podporządkowane temu samemu celowi. Te kanały już zostały wymienione: teatr, muzyka, sport, zabawy itp. Na jakość systemu mieli wówczas wpływ wszyscy, bo wszyscy w nim uczestniczyli. Był 
to - wspomniany wyżej - echosystem. Komunikacja masowa realizowana przez telewizję, radio i prasę takich możliwości nie daje (Eco 1981, s. 105)..

Tekst Umberto Eco powstał przed dobą internetu, ale niejako zapowiedział nadejście czasu rozproszonych kanałów komunikacji. Jednak w czasach księdza Bosko wzajemna komunikacja odbywała się w „żywym” świecie. Dzisiaj natomiast zdecydowana większość komunikatów przepływa co prawda milionami prywatnych i oficjalnych kanałów, ale w wirtualnej przestrzeni internetu. Wszyscy mogą tak przesłać swój komunikat. To współczesne narzędzie daje ogromne możliwości, ale jest jednocześnie przestrzenią komunikacji, w której niemal każdy ma takie samo prawo głosu. Tym samym odpowiedzialność za jakość komunikacji zostaje przeniesiona na każdego człowieka.

Umiejętne połączenie przestrzeni żywego i wirtualnego oratorium, czyli także dwóch różnych przestrzeni komunikacji społecznej, jest wyzwaniem, które salezjanie dzisiaj przed sobą stawiają. Mają świadomość, że „w wirtualu” mogą spotkać wielu młodych, ale tylko „w realu” ci młodzi spotkają Zbawiciela w sakramencie pokuty i Eucharystii.

\title{
Bibliografia
}

Eco U. A lezione da don Bosco. „L'Espresso”, 15.11.1981.

\section{THE SALESIANS AND THE MEDIA}

\begin{abstract}
The means of social communication are the tools that help in the wider education and pastoral Salesian service for young people. Therefore it is placed in the context of the Salesian Social Communication System that continuous communication style introduced by Don Bosco in Valdocco. The Apostle of Young People, who was also a writer, publicist, publisher, and distributor, appreciated the traditional means of social communication - theatre and music. The social communication instruments were also used in games and competitive sports. This became the foundation for modern communication system that translates the range of involvement and personal attitudes of those who agree to create an environment which is a real community of sharing ideals, values, relationships at the level of daily living in a community and a neighbourhood, understood either as 'real' or 'virtual'.
\end{abstract}

Key words: new media, communication, Salesians, John Bosco

Wojciech Kułak - salezjanin. Od 1999 roku mieszka i pracuje w Łodzi. Od 2001 roku redaguje portal młodzieżowy Bosko.pl, a od 2015 Tominowina.pl, witrynę poświęconą chrześcijańskim nowościom wydawniczym. 